\title{
Evaluation and Management of Early Onset Genetic Obesity in Childhood
}

\author{
Sonali Malhotra ${ }^{1}$ Ramya Sivasubramanian ${ }^{2}$ Gitanjali Srivastava ${ }^{30}$ \\ ${ }^{1}$ Department of Pediatric Endocrinology, Massachusetts General \\ Hospital for Children, Harvard Medical School, Boston, \\ Massachusetts, United States \\ 2 Division of Pediatric Nephrology, The Children's Hospital of \\ Philadelphia, Philadelphia, Pennsylvania, United States \\ ${ }^{3}$ Department of Medicine; Department of Pediatrics; Department of \\ Surgery; Division of Endocrinology, Diabetes \& Metabolism, \\ Vanderbilt University School of Medicine, Nashville, Tennessee, \\ United States

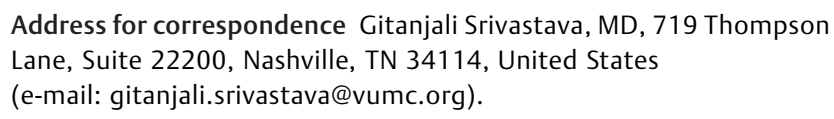
Lane, Suite 22200, Nashville, TN 34114, United States (e-mail: gitanjali.srivastava@vumc.org). \\ J Pediatr Genet 2021;10:194-204.
}
Abstract
Keywords
- infantile obesity
- genetic obesity
- hyperphagia
- weight-for-length percentile
- pediatric weight management
- pediatric obesity

One in five children and adolescents in the United States are diagnosed with obesity and nearly $6 \%$ of them are being classified under the severe obesity category. With over $7 \%$ of severe obesity being attributed to genetic disorders, in this review we aim to focus on monogenic and syndromic obesity: its etiology, wide spectrum of clinical presentation, criticalness of early identification, and limited management options. Advanced genetic testing methods including microarray and whole genome sequencing are imperative to identify the spectrum of mutations and develop targeted treatment strategies including personalized multidisciplinary care, use of investigational drugs, and explore surgical options in this unique subset of severe pediatric obesity.

\section{Introduction}

Obesity in pediatrics is rising at an alarming speed, with one in five children and adolescents in the United State having obesity and nearly $6 \%$ of them being classified in the severe obesity category. ${ }^{1}$ The most common form is polygenic obesity, meaning that cumulative impact of multiple genes contributes to excessive weight gain. Single-gene mutations, predominantly located in the leptin-melanocortin pathway, can lead to monogenic obesity. On the contrary, another form known as syndromic obesity is obesity occurring in the setting of multiple organ system involvements. ${ }^{2}$ In this review, we aim to focus on monogenic and syndromic obesity only and highlight a clinical case to enhance further understanding.

\section{Clinical Case}

A 7-month-old girl child patient presented to the office with exponential weight gain and a weight-for-length much above the 99th percentile. She was born full term with a birth weight of 7 pounds 9 ounces. Pregnancy was uneventful. Mother expressed worry over the infant wearing size 3T clothing and inconsolable fussiness if not offered a bottle on time. On review of the growth charts, her weight was at the 93rd percentile at the age of 2 months and then progressively increased to much above the 99th percentile. Between the age of 2 and 4 months, she had gained close to 11 pounds. At 7 months of age when she presented to pediatric endocrinology clinic, she was $>99$ th percentile (standard deviation score $[\mathrm{SDS}]=3.01$ ) for her length. Weight was $>99$ th received

February 18, 2021

accepted

April 16, 2021

published online

July 3, 2021 (c) 2021. Thieme. All rights reserved.

Georg Thieme Verlag KG,

Rüdigerstraße 14

70469 Stuttgart, Germany
DOI https://doi.org/

10.1055/s-0041-1731035. ISSN 2146-4596. 

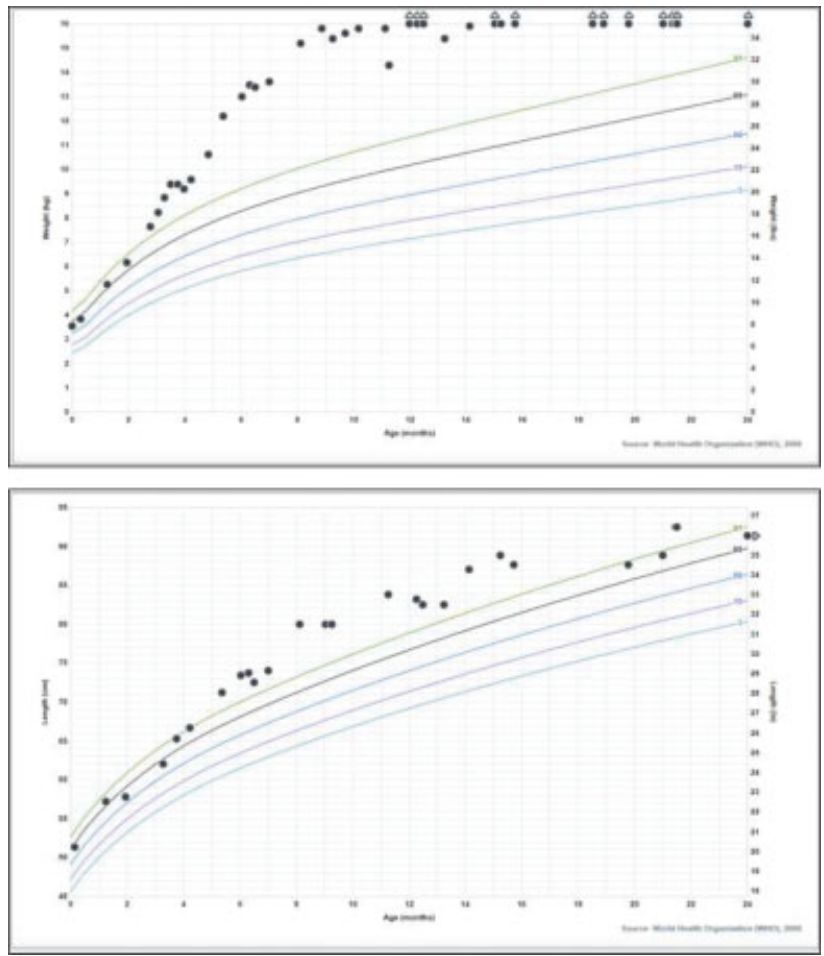

Fig. 1 Weight and length growth charts.

percentile (SDS $=5.07$ ), weight for length $>99$ th percentile, SDS of +4.29 (-Fig. 1). Additionally, she had a history of recurrent respiratory infections that led to a video fluoroscopic study demonstrating an increased risk of aspiration. Thus, she was recommended to thicken her formula feeds. Her diet comprised of some pureed fruits and vegetables. Developmentally, she was on track and achieving age-appropriate milestones. Family history was noncontributory.

\section{Discussion}

\section{Prevalence of Genetic Obesity Among all Obesity Etiologies}

Literature reports approximately $7 \%$ of severe pediatric obesity is attributed to genetic disorders, ${ }^{3}$ though actual global prevalence of monogenic and syndromic obesity in the pediatric population is not well known. It has also been shown that close to $3 \%$ of individuals with severe, early onset obesity have leptin receptor gene (LEPR) mutations, ${ }^{4,5}$ of which 65 out of the 88 cases identified worldwide are in the pediatric age group. ${ }^{6}$ Other genetic defects involving POMC, PCSK1, NTRK2, and SIM 1 have lesser than 10 to 50 cases identified worldwide. In total, 3 to $6 \%$ have melanocortin 4 gene (MC4R) mutations, the most commonly reported monogenic obesity worldwide. ${ }^{7-11}$ Notably, infants and young children of some ethnicities have demonstrated a monogenic obesity prevalence as high as $15 \%{ }^{12}$ Additionally, at present over 25 syndromic forms of obesity have been identified. ${ }^{2}$ Among syndromic obesity disorders, Prader-Willi syndrome (PWS) is the most prevalent syndromic obesity with a birth incidence of $1 / 10,000$ to $1 / 30,000$, and an estimated prevalence of approximately 10,000 to 20,000 living individuals in the United States with clinical manifestations presenting in early childhood. ${ }^{13}$ Moreover, recent studies have observed that due to lack of consensus on identifying and evaluating symptoms of genetic defects in a timely manner, a vast majority of patients are undertested, leading to a reportedly lowered prevalence. ${ }^{14}$

\section{Physiology of Energy Balance}

There are broadly two pathways that maintain energy balance: (1) "metabolic or homeostatic" pathway involving energy intake as well as energy expenditure and (2) the "hedonic" pathway, which is involved in the reward or pleasure based eating. ${ }^{15}$ Physiologically, these pathways work jointly to regulate feelings of hunger and satiety. As demonstrated in -Fig. 2, this is modulated through neural circuits in the hypothalamus involving gut hormones, vagal nerve, neuropeptide Y/agouti related protein (NPY/AgRP) neurons, and neuropeptides: orexin and melanin concentrating hormone $(\mathrm{MCH})$, proopiomelanocortin (POMC) neurons, proprotein convertase subtilisin/kexin type 1 (PCSK1) and $M C 4 R .^{16,17}$ Efferent and afferent signaling affect the energy regulatory pathways. In addition, microenvironment and macroenvironment influences, early life events, biological and genetic influences, and epigenetic changes including germline genetic variations in the microbiota can affect energy balance pathology. ${ }^{18}$

\section{Key Components in Assessment of a Child with Obesity}

Defining and Classifying Severity of Pediatric Obesity

Weight management strategies for a child with obesity take into account both age of the child and severity of obesity. BMI is the preferred tool in children and adolescents above 2 years of age. Infants are assessed by using either Center for Disease Control (CDC) Charts or World Health Organization (WHO) charts. CDC charts are based mostly on formula-fed infants, predominantly Caucasian American origin, whereas WHO charts are derived from mostly breastfed infants of various racial and ethnic diversities in different parts of the world. ${ }^{19}$ Close monitoring is recommended in infants with increasing percentile trajectories or abrupt changes in a short time compared with those displaying a stable growth trajectory. ${ }^{20}$ Infants, up to 2 years of age with weight for recumbent length being $\geq 97.7$ th percentile of WHO growth standards, are diagnosed with obesity. ${ }^{21,22}$

Children and adolescents over the age 2 years are assessed by using Body Mass Index Charts formulated by CDC. ${ }^{19}$ However, to assess the severity of obesity and to better classify it in this age group, BMI percentiles are used, ${ }^{23}$ where BMI is expressed as a "percent of the 95th percentile" ( - Tables 1 and $\mathbf{2}$ ). This is the patient's BMI divided by the BMI value at the 95th percentile for the patient's age and sex (e.g., if the 95th percentile BMI value is $20 \mathrm{~kg} / \mathrm{m}^{2}$ and the patient's BMI is $30 \mathrm{~kg} / \mathrm{m}^{2}$, the patient's BMI would be $150 \%$ of the $95 \mathrm{th}$ percentile). 

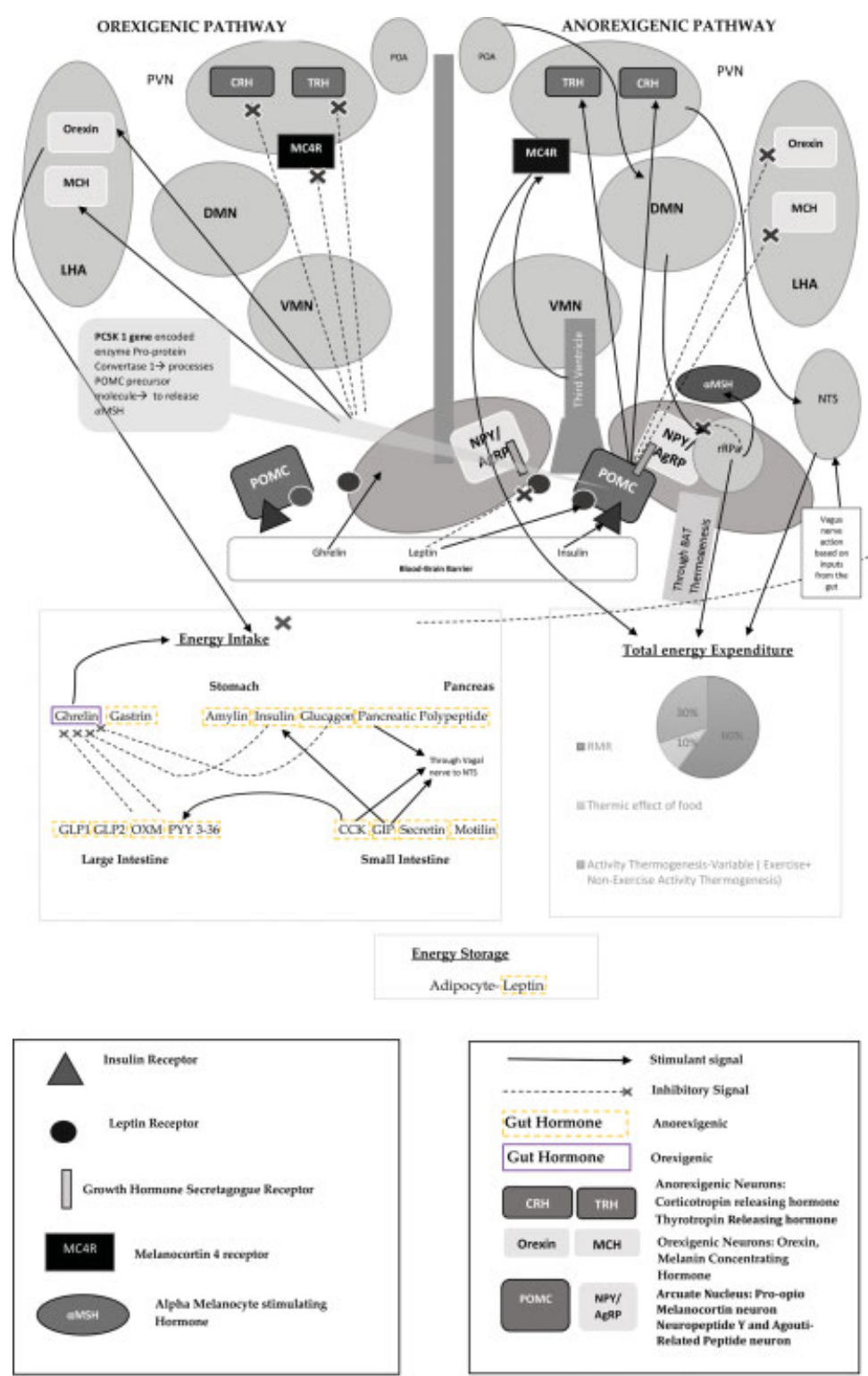

Fig. 2 Energy balance mechanism. Orexigenic pathway (positive balance): Ghrelin is released from the fundus mucosa before a meal/state of empty stomach. It is a natural ligand that acts on the GHSR which is expressed throughout the brain and especially in the NPY/AgRP neurons in the Arcuate Nucleus. On binding the GHSR, ghrelin acts on the lateral hypothalamic area to stimulate orexigenic neuropeptides: orexin and melanin concentrating hormone, which, in turn stimulate feeding behavior. It also stimulates the NPY/AgRP neurons that acts as an antagonist on MC4-R expressed in the paraventricular nucleus preventing the function of MC4-R, which is to inhibit food intake. NPY/AgRP neurons on activation also inhibit the anorexigenic neurons TRH and CRH in the PVN, thereby facilitating feeding behavior "Hunger." 16,17 Anorexigenic pathway (negative balance): Gut hormones like PYY3-36, oxyntomodulin, insulin, glucagon participate in inhibition of appetite-stimulant, ghrelin. Insulin crosses the blood-brain barrier at arcuate nucleus to bind the insulin receptor on POMC neurons. Meanwhile, leptin released from the adipocytes bind the leptin receptors on POMC neurons and inhibiting NPY/AgRP, thereby stimulating and inhibiting them, respectively. On receiving these stimuli, POMC inhibits the orexigenic NPY/AgRP and releases alpha MSH ${ }^{79}$ to bind MC4-R which in turn promotes energy expenditure while inhibiting feeding behavior. POMC neurons also stimulate anorexigenic neurons: TRH and CRH in PVN to stimulate satiety and inhibit orexigenic neurons: $\mathrm{MCH}$ and orexin. Other stimuli like stretch of stomach, gut hormones signals that reach PVN through vagus nerve will further promote satiety through nucleus tractus solitarius. External factors like cold exposure can stimulate preoptic area, which sends signals to the dorsomedial hypothalamic nuclei, which in turn send signals to rRPa. On receiving stimuli rRPa induces thermogenesis through brown adipose tissue, thereby promoting energy expenditure. ${ }^{16,17}$ Total energy expenditure = resting metabolic rate (energy spent during state of rest during periods of wakefulness as well as sleep) + thermic effect of food (energy spent in food storage, digestion, and absorption) + activity thermogenesis (which is the sum of energy spent during exertional activities as well as nonexercise activity: maintaining body in upright postures). ${ }^{80,81} \mathrm{AgRP}$, agouti-related protein; BAT, brown adipose tissue; CCK, cholecystokinin; CRH, corticotrophin releasing hormone; DMN, dorsomedial hypothalamic nucleus; GIP, gastric inhibitory polypeptide; GLP 1 and GLP 2, glucagon like peptide 1 and 2; GHSR, growth hormone secretagogue receptor; OXM, oxyntomodulin; LHA, lateral hypothalamic area; MCH, melanin concentrating hormone; MC4R, melanocortin 4 receptor; NTS, nucleus tractus solitarius; NPY, neuropeptide Y; POA, preoptic area; PCSK1, proprotein convertase subtilisin/kexin type 1; POMC, pro-opiomelanocortin (precursor of melanocyte stimulating hormone); PVN, paraventricular nucleus; ; PYY 3-36, peptite YY; rRPa, raphe pallidus; VMN, ventromedial hypothalamic nuclei. 
Table 1 Classification of children and adolescents based on pediatric endocrine society recommendations

\begin{tabular}{|l|l|}
\hline Children below 2 y of age \\
\hline Obesity & $\begin{array}{l}\text { Weight for recumbent length } \\
\geq 97.7 \text { th percentile of WHO } \\
\text { growth standards }\end{array}$ \\
\hline Children and adolescents $2-20$ y of age \\
\hline Overweight & $\begin{array}{l}\text { BMI } \geq 85 \text { th to }<95 \text { th percentile for } \\
\text { age and sex }\end{array}$ \\
\hline Obesity & BMI $\geq 95$ th percentile for age and sex \\
\hline Severe Obesity & $\begin{array}{l}\text { BMI } \geq 120 \% \text { of } 95 \text { th percentile } \\
\text { or BMI } \geq 35 \mathrm{~kg} / \mathrm{m}^{2}, \text { whichever is lower }\end{array}$ \\
\hline
\end{tabular}

Abbreviations: BMI, body mass index; WHO, world health organization.

\section{What Is Early Onset Obesity?}

Endocrine society clinical practice guideline recommends that extreme obesity before the age of 5 years must be considered as early-onset obesity. ${ }^{22}$ These children in the presence of hyperphagia should be evaluated for other associated conditions such as endocrinopathies and developmental anomalies.

\section{Hyperphagia: A Key Presenting Symptom in Monogenic and Syndromic Obesity}

One of the most distinctive features associated with genetic (monogenic or syndromic) obesity is hyperphagia. ${ }^{24}$ Overeating behaviors can be classified based on severity. Overeating can range from occasional overeating (which is considered normal) to hedonic overeating (eating in the absence of physiological hunger) to binge eating, and ultimately, the most severe form known as hyperphagia. ${ }^{24}$ It is crucial to note that the objective assessment of hyperphagia still remains a major challenge in clinical practice. Even though we do not have a clear consensus on an assessment tool yet to distinguish overeating from hyperphagia, over the years several questionnaires have been formulated to objectively assess various aspects of hyperphagia. ${ }^{24}$

"The hyperphagia questionnaire" consists of 13 items to assess three major aspects of hyperphagia: behavior, drive, and severity. ${ }^{25}$ This is validated specifically in children with Prader-Willi syndrome. The questionnaire assesses inputs from both the parents as well as the patient based on a 5point severity scale. The three major components assessed are the hyperphagic behavior, drive, and severity. Hyperphagic behavior survey facilitates assessment of the ability of a child to obtain food by clever bargains, manipulation, seeking food from trash, night-eating, and stealing. Hyperphagic drive includes distress on food denial, distractibility from the fixation on food related thoughts. Hyperphagic severity is assessed by evaluating the amount of time in a day spent on thoughts related to food and consequential degree of functional impairment ${ }^{35}$. Another scale called, "The Three-Factor Eating Questionnaire" was formulated combining concepts from two previously
Table 2 Classification of obesity

\begin{tabular}{|l|l|}
\hline Class I & $\begin{array}{l}\text { BMI } \geq 95 \text { th percentile to }<120 \% \\
\text { of } 95 \text { th percentile for age and sex }\end{array}$ \\
\hline Class II & $\begin{array}{l}\mathrm{BMI} \geq 120 \% \text { to }<140 \% \text { of } 95 \text { th percentile } \\
\text { or } \mathrm{BMI} \geq 35 \mathrm{~kg} / \mathrm{m}^{2}\end{array}$ \\
\hline Class III & $\mathrm{BMI} \geq 140 \%$ of 95 th percentile or $\mathrm{BMI} \geq 40 \mathrm{~kg} / \mathrm{m}^{2}$ \\
\hline
\end{tabular}

Abbreviation: BMI, body mass index.

designed questionnaires that evaluated "restrained eating" and "latent obesity." This questionnaire also had several added items as part of its survey and was validated across several populations consistently undergoing multiple adaptations in an attempt to account for patients across the dietary spectrum from extreme restraint to extreme lack of restraint. The "Three-Factor Eating Questionnaire" identified three stable factors as crucial for analysis: (1) cognitive restraint of eating, (2) disinhibition, and (3) hunger. ${ }^{25}$ Similarly, the "Dutch Eating Behavioral Questionnaire" which identified differences in consumption of food in response to labeled emotions versus diffuse emotions indicating an overeating response in the latter. Lastly, "The Power of food" scale has been reported to be a useful method to investigate the hedonic impact in individuals exposed to highly palatable food supplied environment. ${ }^{26}$

\section{Associated Features of Monogenic and Syndromic Obesity}

Apart from hyperphagia and severe early onset obesity, several associated features may present clinically in these children including a range of endocrinopathies, developmental delays, cardiac and renal anomalies, retinal changes, and distinct organ system involvement. - Fig. 3 provides a stepwise algorithm for the assessment of a patient with suspicion of genetic forms of obesity (-Fig. 3 and - Table 3 and $\mathbf{4}$ ).

Monogenic forms of obesity such as leptin deficiency and leptin receptor (LEPR) mutations can present with short stature, pubertal delay, hypothyroidism emotional labiality, intellectual disability, and altered immune function. Even though they present similarly, LEPR mutations are much more prevalent compared with congenital leptin deficiency. ${ }^{4,5,27}$ MC4R mutations (the most commonly affected in the leptin-melanocortin pathway) present with tall stature with increased lean mass and tall stature as well as severe hyperinsulinemia $^{7-11}$ (- Table 3).

Syndromic obesity, on the other hand, commonly present with developmental delay in children along with characteristic sets of clinical features as outlined in -Table 4. For example, Prader-Willi syndrome is the classical form of syndromic obesity which can present with low birth weight, severe hypotonia and feeding difficulties during early infancy, characteristic facial features, strabismus and scoliosis, and behavioral disorders. ${ }^{28-32}$ Some of the other forms of syndromic obesity include Bardet-Biedl syndrome (BBS). Patients with BBS present can have retinitis pigmentosa, rod-cone retinal dystrophy, polydactyly hypogonadotropic hypogonadism with genital malformations, and renal and 

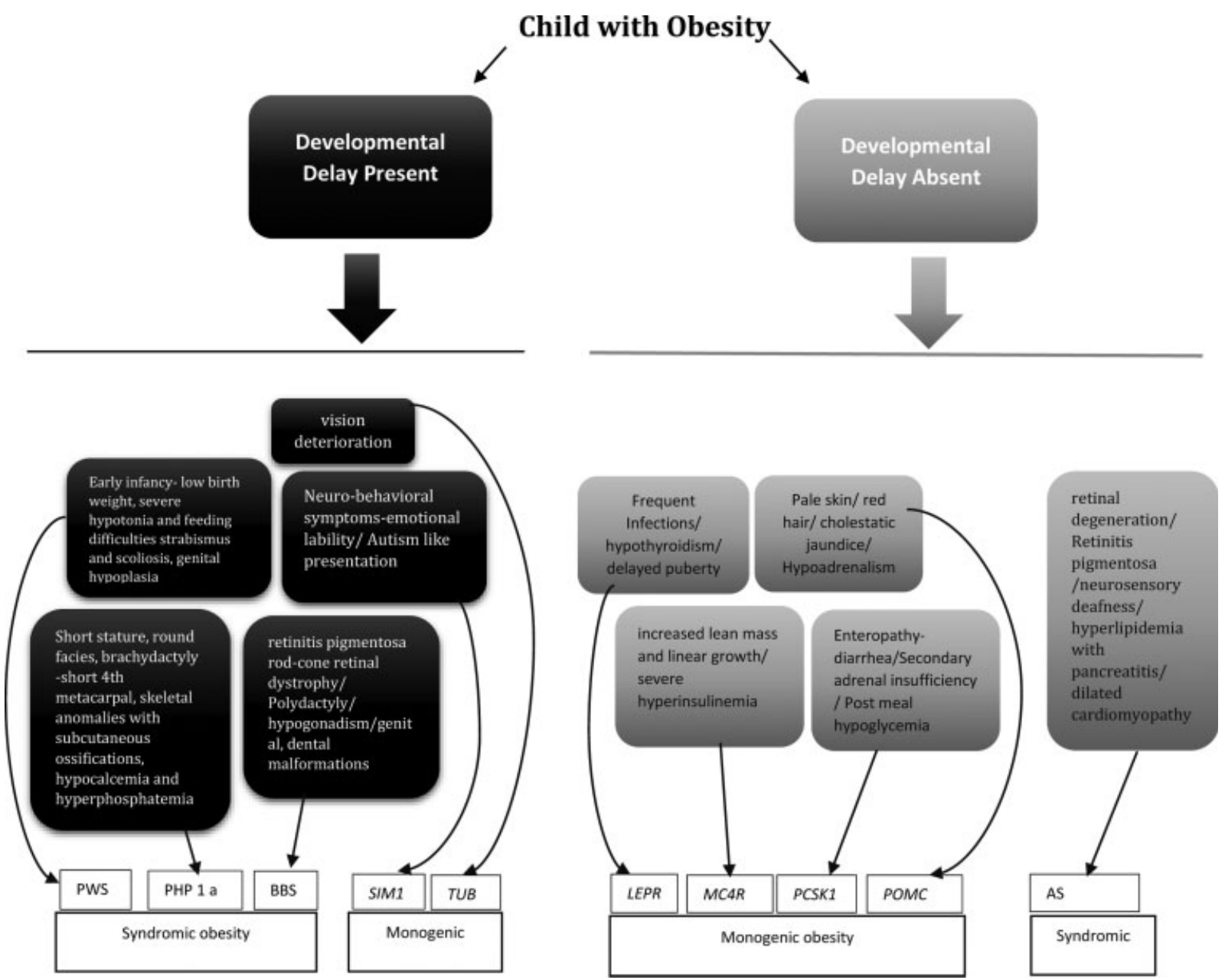

Fig. 3 Diagnostic clues in a clinical setting. ${ }^{6-10,24,30-47}$ AS, Alström syndrome; BBS, Bardet-Biedl syndrome; LEPR, leptin deficiency/leptin receptor mutation; MC4R, melanocortin 4 receptor mutation; PCSK1, proprotein convertase deficiency; PHP 1a-pseudohypoparathyroidism 1 a; POMC, pro-opiomelanocortin deficiency; PWS, Prader-Willi syndrome; SIM 1, single-minded homolog 1 gene defect; TUB, Tubby bipartite transcription factor.

dental defects. ${ }^{33,34}$ Several other known syndromes and their associated features are enlisted in - Table 4.

\section{Genetic Testing}

The Significance of Establishing a Genetic Diagnosis Obesity is often inappropriately disregarded as an outcome of patient's lifestyle choices, leading to severe social stigma and exposing patients to being considered as "lazy," lacking willpower and self-discipline.

Genetic testing and identifying an underlying genetic cause of obesity, gives patient and their families the ability to acknowledge an ongoing pathology, leading to reduced self and societal blame. Not just amongst patients, obtaining a definitive diagnosis can also help their families cope with stress of the unknown. Hyperphagia has been found to cause significant distress both for the patients as well as their caregivers. ${ }^{24}$ A study demonstrated that compared with controls, siblings of patients with hyperphagia reported poorer quality of life and over 92\% of siblings were noted to suffer from moderate to severe symptoms of posttraumatic stress disorder. ${ }^{35}$
Identifying the underlying genetic etiology can help manage patients' and family's concerns early on in the disease and treat associated endocrinopathies, hyperphagia, and other metabolic risks by early targeted, multidisciplinary treatment of the underlying cause.

\section{What Does Genetic Testing Entail?}

Pediatric Endocrine society guideline recommends genetic testing in children with extreme, early-onset obesity before 5 years of age with hyperphagia, and/or family history of extreme obesity. ${ }^{22}$ Patients presenting with the features described above should undergo next generation sequencing (NGS) of the genes postulated to be involved in the clinical phenotype.

It is important to examine the most optimal application of NGS in diagnosis of genetic disorders. Gene panels are considered 1-tier tests as they entail low costs, have a rapid turnaround time, low rate of nonspecific findings. ${ }^{36}$ While it is favored because of its affordability, accessibility and quicker results, notably gene panels miss approximately $10 \%$ of mutations that can be detected by whole exome sequencing (WES) that provides superior coverage 
Table 3 Monogenic obesity

\begin{tabular}{|c|c|c|}
\hline Genetic defect & Prevalence & Clinical features \\
\hline $\begin{array}{l}\text { Leptin } \\
\text { deficiency } 4,24\end{array}$ & $\begin{array}{l}\text { Prevalent with consanguinity } \\
\text { lesser than } 1,000 \text { cases identified worldwide }\end{array}$ & $\begin{array}{l}\text { - Short stature, emotional lability, intellectual dis- } \\
\text { ability } \\
\text { - Hyperphagia } \\
\text { - Delayed puberty due to hypogonadotropic hypogo- } \\
\text { nadism } \\
\text { - Hypothyroidism }\end{array}$ \\
\hline $\begin{array}{l}\text { Leptin receptor } \\
\text { mutation } 5,24\end{array}$ & $\begin{array}{l}\text { 3\% of individuals with severe onset obesity } \\
\text { may have LEPR mutation. Hyperphagia onset } \\
\text { in neonates within one week after birth. }\end{array}$ & $\begin{array}{l}\text { - Alteration in immune function } \\
\text { - Delayed puberty due to hypogonadotropic hypogo- } \\
\text { nadism } \\
\text { - Severe hyperphagia }\end{array}$ \\
\hline $\begin{array}{l}\text { Melanocortin } 4 \\
\text { receptor } \\
\text { mutation }^{6-10,32}\end{array}$ & $\begin{array}{l}\text { Codominance inheritance or rarely homozy- } \\
\text { gous (more severe presentation) } \\
\text { Identified in 3-6\% of children with severe } \\
\text { early onset obesity, is, BMI }>40 \mathrm{~kg} / \mathrm{m}^{2}\end{array}$ & $\begin{array}{l}\text { - Severe obesity } \\
\text { - Hyperphagia } \\
\text { - Increased lean mass and linear growth } \\
\text { - Severe hyperinsulinemia }\end{array}$ \\
\hline $\begin{array}{l}\text { Pro-opiomelanocor- } \\
\text { tin } \\
\text { deficiency } \\
\text { 30,33,34 }\end{array}$ & $\begin{array}{l}\text { Diagnosed in lesser that } 10 \text { individuals } \\
\text { worldwide } \\
\text { Onset of symptoms in first few months of life }\end{array}$ & $\begin{array}{l}\text { - Severe early-onset obesity, hyperphagia } \\
\text { - Cholestatic jaundice in infants. } \\
\text { - The classic triad is obesity, adrenal insufficiency, and } \\
\text { pale skin pigmentation with red hair }\end{array}$ \\
\hline $\begin{array}{l}\text { Proprotein conver- } \\
\text { tase deficiency }\end{array}$ & Lesser that 20 cases identified worldwide & $\begin{array}{l}\text { - Early-onset obesity } \\
\text { - Moderate } \\
\text { hyperphagia } \\
\text { - Postprandial hypoglycemia and } \\
\text { enteropathy causing diarrhea. } \\
\text { - ACTH deficiency causing secondary } \\
\text { - Adrenal insufficiency, hypogonadotropic hypogo- } \\
\text { nadism impaired glucose tolerance }\end{array}$ \\
\hline $\begin{array}{l}\text { Neurotrophic tyro- } \\
\text { sine kinase receptor } \\
\text { type } 2 \text { mutation }\end{array}$ & Lesser that 10 cases identified worldwide & $\begin{array}{l}\text { - Early-onset obesity } \\
\text { - Hyperphagia } \\
\text { - Developmental delay } \\
\text { - Short-term memory impairment } \\
\text { - Nociception anomalies }\end{array}$ \\
\hline $\begin{array}{l}\text { Brain-derived neu- } \\
\text { rotrophic factor } \\
\text { gene defect }\end{array}$ & & $\begin{array}{l}\text { - Hyperphagia } \\
\text { - Severe obesity } \\
\text { - Cognitive impairment } \\
\text { - Hyperactivity }\end{array}$ \\
\hline $\begin{array}{l}\text { Single-minded ho- } \\
\text { molog1 gene }\end{array}$ & Lesser that 50 cases identified worldwide & $\begin{array}{l}\text { - Severe obesity } \\
\text { - Neurobehavioral abnormalities } \\
\text { (emotional lability or autism like presentation) }\end{array}$ \\
\hline $\begin{array}{l}\text { Tubby bipartite } \\
\text { transcription } \\
\text { factor }^{38}\end{array}$ & & $\begin{array}{l}\text { - Obesity } \\
\text { - Characteristic vision deterioration }\end{array}$ \\
\hline
\end{tabular}

Abbreviations: BMI, body mass index; LEPR, Leptin receptor; WHO, world health organization.

of targeted gene panels with greater number of genes included. ${ }^{37}$

WES is a testing method which facilitates fast and accurate ways to explore genetic basis of diseases such as obesity. ${ }^{38}$ It is rapidly becoming a first-line approach in evaluation of monogenic disorders, and surplus evidence has noted for its significant utility in clinical practice. ${ }^{39,40}$ Advanced genetic testing techniques using WES and microarray helps drive the future toward precision medicine in pediatric obesity.

WES identifies a subset of genome and sequences the exon DNA using any high-throughput DNA sequencing technology. ${ }^{41}$ This is to identify those defective genetic variants that are potentially altering protein sequences. However, the performance of WES is sensitive to sequence (GC) content as well as capturing design and enrichment making it less favorable compared with whole genome sequence (WGS). WGS provides a more comprehensive coverage of the exome and other clinically relevant genomic sequences. ${ }^{36}$ While WGS compared with WES is more expensive and has a higher turnaround time, genome-wide read coverage may allow a reliable detection of copy number variations (CNVs), which can contribute substantially to disease burden. ${ }^{36,42}$

While studying genome, variant allele frequency is of vital consideration. Generally, the terms rare and common variants is used to define those with minor allele frequency $<1 \%$ and $>5 \%$, respectively. ${ }^{43}$ Even though NGS has helped identify many diverse subgroups of patients across diseases with several variants, studying large enough populations to have 
Table 4 Syndromic obesity

\begin{tabular}{|c|c|c|}
\hline $\begin{array}{l}\text { Prader-Willi } \\
\text { syndrome }\end{array}$ & $\begin{array}{l}\text { Most common cause of } \\
\text { syndromic obesity }\end{array}$ & $\begin{array}{l}\text { - PWS Early infancy: low birth weight, severe hypotonia, and feeding difficulties } \\
\text { - PWS Early childhood: excessive eating and gradual development of morbid obesity } \\
\text { - PWS Characteristic facial features, strabismus, and scoliosis } \\
\text { - PWS Developmental delay: motor milestones, social, and language development delay with } \\
\text { various degrees of cognitive impairment } \\
\text { - PWS Behavioral disorders } \\
\text { - PWS Hypogonadism with genital hypoplasia, incomplete pubertal development, infertility, and } \\
\text { short stature }\end{array}$ \\
\hline Alström syndrome ${ }^{30}$ & $\begin{array}{l}\text { Nearly } 700 \text { cases de- } \\
\text { scribed } \\
\text { worldwide }\end{array}$ & $\begin{array}{l}\text { - Obesity and type } 2 \text { diabetes mellitus } \\
\text { - Retinal degeneration } \\
\text { - Retinitis pigmentosa onset } 15 \text { mo of age } \\
\text { - Neurosensory deafness before } 10 \text { y of age } \\
\text { - Hyperlipidemia with pancreatitis by } 5 \text { y of age } \\
\text { - Dilated cardiomyopathy or congestive heart failure in } 70 \% \text { of patients by adolescence }\end{array}$ \\
\hline $\begin{array}{l}\text { Bardet-Biedl } \\
\text { syndrome }^{30,31}\end{array}$ & $\begin{array}{l}\text { Below 1: 100,000. } \\
\text { (in Europe and North } \\
\text { America) }\end{array}$ & $\begin{array}{l}\text { - Marked obesity and hyperphagia } \\
\text { - Retinitis pigmentosa, rod-cone retinal dystrophy } \\
\text { - Polydactyly } \\
\text { - Hypogonadotropic hypogonadism with genital malformations } \\
\text { - Renal defects } \\
\text { - Significant developmental delay, speech deficit, ataxia, or poor coordination, } \\
\text { - Olfactory deficit, dental defects } \\
\text { - T2DM and congenital heart disease }\end{array}$ \\
\hline $\begin{array}{l}\text { Pseudohypoparathyr- } \\
\text { oidism type } 1 a^{41}\end{array}$ & Autosomal dominant & $\begin{array}{l}\text { - Obesity } \\
\text { - Short stature, round } \\
\text { facies, brachydactyly; typically, short 4th metacarpal, and } \\
\text { other skeletal anomalies with subcutaneous ossifications } \\
\text { - Hypocalcemia and hyperphosphatemia. }\end{array}$ \\
\hline WAGRO syndrome ${ }^{42}$ & & $\begin{array}{l}\text { - Obesity } \\
\text { - Aniridia } \\
\text { - Ambiguous genitalia } \\
\text { - Mental retardation } \\
\text { - Wilms tumor }\end{array}$ \\
\hline Cohen syndrome 43 & $\begin{array}{l}\text { Autosomal recessive } \\
\text { disorder }\end{array}$ & $\begin{array}{l}\text { - Obesity } \\
\text { - Hypotonia } \\
\text { - Distinctive facial features and microcephaly } \\
\text { - Nonprogressive psychomotor retardation } \\
\text { - Motor abnormalities } \\
\text { - Progressive myopia }\end{array}$ \\
\hline $\begin{array}{l}\text { Smith-Magenis } \\
\text { syndrome }\end{array}$ & & $\begin{array}{l}\text { - Obesity } \\
\text { - Neurobehavioral disorder } \\
\text { - Sleep disturbance } \\
\text { - Multiple developmental anomalies }\end{array}$ \\
\hline $\begin{array}{l}\text { Borjeson-Forssman- } \\
\text { Lehmann }^{45}\end{array}$ & & $\begin{array}{l}\text { - Obesity } \\
\text { - Severe mental disability } \\
\text { - Microcephaly } \\
\text { - Epilepsy } \\
\text { - Hypogonadism } \\
\text { - gynecomastia }\end{array}$ \\
\hline $\begin{array}{l}\text { Carpenter syndrome/ } \\
\text { acrocephalopolysyndac- } \\
\text { tyly type }{ }^{46}\end{array}$ & & $\begin{array}{l}\text { - Obesity } \\
\text { - Acrocephaly } \\
\text { - Preaxial polydactyly, soft tissue syndactyly, brachy- or agenesis mesophalangy of the hands and } \\
\text { feet } \\
\text { - congenital heart disease } \\
\text { - Hypogenitalism } \\
\text { - Umbilical Hernia } \\
\text { - Intellectual deficits }\end{array}$ \\
\hline Kabuki syndrome ${ }^{47}$ & & $\begin{array}{l}\text { - Obesity } \\
\text { - Characteristic facial features } \\
\text { - Intellectual deficits } \\
\text { - Visceral and skeletal malformations } \\
\text { - Growth deficiency and several endocrinopathies }\end{array}$ \\
\hline
\end{tabular}

Abbreviations: LEPR, leptin receptor; ROHHAD, rapid-onset obesity with hypoventilation, hypothalamic dysfunction, and autonomic dysregulation; WAGRO, Wilms tumor, aniridia, genitourinary abnormalities, and intellectual disability. 
statistically significant findings continues to be a challenge with NGS. Using the identified rare variants of uncertain significance for clinical progress, making interpretations and performing more controlled clinical trials for personalized medicine requires updated disease databases, predictive algorithms, and in vitro functional assays. ${ }^{44}$ In the case, initial tests fail to yield results and yet the patient is strongly suspected to have a syndromic obesity presentation, the best next steps would include wide genome sequencing. ${ }^{14}$

\section{Management Options}

\section{Lifestyle Management in Monogenic and Syndromic Obesity}

It is critical to understand when managing a child with hyperphagia associated with genetic obesity such as PWS, that they do not have the intact physiological huger-satiety feedback. ${ }^{45}$ Therefore, nutritional counseling used in metabolic disorders and polygenic obesity (without severe hyperphagia) may not be effective in these children. At the same time, the caloric needs of infants and children with PWS are significantly lower (40-70\%) because of their decreased resting energy expenditure. This indicates that ensuring 60 to $80 \%$ of recommended daily allowance is appropriate to maintain a stable body weight without excess weight gain. ${ }^{28-30}$ Management strategies to a large extent must focus on reducing food-related preoccupation apart from controlling access to food. Emotional outbursts, tantrums, and sudden shut downs are noted as a part of behavioral disturbances in a child with PWS with hyperphagia. ${ }^{24}$

PWS patients are notably adverse to any form of physical exercise owing to the fatigue induced stress and tantrums. ${ }^{46}$ However, a study involving a 4-week long residential program occurring four times a year has demonstrated benefits of intense lifestyle management in PWS patients. ${ }^{46}$ Apart from restricted calorie intake, this study involved 6.5 hours of physical exercise daily with motivating stimuli to build stamina using music therapy, psychomotor therapy, education, and entertainment activities. BMI decreased by 2.1 average points in every residential session. Regular program compliance yielded a reduction of 8.9 points over 6 years, hence highlighting the efficacy of exercise on weight loss in PWS. ${ }^{46}$

Focusing on monogenic obesity conditions like MC4R defects, no difference has been shown in achieving weight reduction with intensive lifestyle intervention in patients with or without MC4R mutation carrier state; however, they do demonstrate difficulty in achieving long-term body weight maintenance. ${ }^{10}$

\section{Pharmacological Management of Genetic Obesity and Future Precision Medicine}

A wide range of drugs have been approved by the Food and Drug Administration (FDA) to treat obesity in adults. However, only Orlistat and Phentermine hold FDA approval for management of pediatric obesity with most recently liraglutide, a GLP 1 agonist being added to the list. Here, we elaborate on drugs that can be used to target monogenic, syndromic, and hypothalamic obesity.

\section{Monogenic Obesity}

A recombinant leptin analogue (metreleptin) that is currently an FDA-approved treatment for congenital and acquired lipodystrophy has shown promise among children with obesity caused by LEP gene defects. ${ }^{47}$ It is effective in reducing hunger and body weight among children and adults with congenital leptin deficiency. ${ }^{47,48}$

Similarly, several studies evaluating MC4R agonist, setmelanotide in the management of monogenic and syndromic obesity have shown promising results both in terms of safety and tolerability. ${ }^{49}$ In phase II study of two adults with POMC mutation associated obesity, setmelanotide reduced body weight without major severe side effects. ${ }^{50}$ Setmelanotide is being actively evaluated as a potential therapy for LEPR variations ${ }^{81}$, POMC deficiency, and Prader-Willi syndrome. ${ }^{51}$ A recent phase III trial studying setmelanotide demonstrated its safety and efficacy in treating severe obesity in patients 6 years or older, caused by POMC or LEPR deficiency. ${ }^{52}$ This study reported results after 1 year of treatment. In total, $80 \%$ of study participants with POMC deficiency and $45 \%$ participants with $L E P R$ deficiency achieved at least $10 \%$ of weight loss and significant reduction in the hunger scores. ${ }^{52}$ The only noted adverse events were injection site reaction, hyperpigmentation, nausea and vomiting, rendering setmelanotide as dependable treatment option.

Sibutramine, a serotonin-norepinephrine reuptake inhibitor, was reported to be beneficial in body weight maintenance as well as improvement in body composition and obesity-related metabolic abnormalities amongst patients with MC4R mutation, ${ }^{53}$ However, FDA has recommended against the continued use of the medication owing its cardiovascular adverse effects. ${ }^{54}$

Inhibition of programmed cell death factor 4 (PDCD4) shows promise as a novel therapy target for metabolic diseases including obesity. PDCD4 has shown to play a crucial role in the regulation of glucose and lipid metabolisms, insulin resistance, oxidative stress, chronic inflammatory response, and dysbacteriosis, which lead to the progression of obesity and other metabolic diseases. By an unknown mechanism PDCD4 has shown to inhibit a transcription factor Liver X receptor $\alpha$ (LXR- $\alpha$ ) and eventually promote the expression of genes related to lipid synthesis and inhibit lipid outflow. 55

\section{Syndromic and Hypothalamic Obesity}

Syndromic obesity management has been a challenge, given the lack of consensus on antiobesity pharmacotherapy in pediatric population as well as the wide range of associated symptoms. However, clinical trials are being actively pursued and several studies involving GLP-1 agonists have shown promising results in syndromic and hypothalamic obesity. Female subjects with Prader-Willi syndrome after 1year use of GLP-1 agonists; (exenatide and liraglutide) had a significant decrease in ghrelin levels, lowered food intake, and BMI. ${ }^{56-58}$ Another study amongst patients with PraderWilli syndrome elucidated increased satiety and lowered

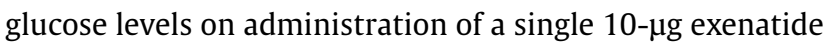
injection when compared with placebo. ${ }^{59}$ Whereas some 
studies have demonstrated lowered appetite scores, without significant change in their weight. ${ }^{60}$ Similarly, clinical trials have shown that exenatide and liraglutide can lead to significant reductions in appetite and weight loss in patients with hypothalamic obesity. ${ }^{61-63}$

Clinical trials involving diazoxide among pediatric patients with hypothalamic obesity has shown varying results on BMI, mandating larger studies in these population to understand its true efficacy. ${ }^{64,65}$

Oxytocin is also noted to be of therapeutic interest. Physiologically, it is produced by the hypothalamus and regulates appetite via hedonic and homeostatic pathways. A recent study has reported the efficacy of investigational therapy involving an oxytocin analog: carbetocin. When administered, intranasally carbetocin showed reduction in hyperphagia $^{45}$

Apart from appetite and weight control, syndromic obesity also requires management of multitude of associated symptoms: serotonin reuptake inhibitors, $\mathrm{N}$-acetylcysteine, or topiramate are used to control skin picking and repetitiveness. Similarly, sex steroids are recommended in the pubertal years in these children to allow for secondary sexual characteristics and optimal bone health. ${ }^{30,66}$

Dysbiotic gut microbiota has shown contributory associations to both genetic and simple obesity in children, implicating a potentially effective therapeutic target. ${ }^{67}$

\section{Surgical Management of Severe Monogenic and Syndromic Obesity}

The most effective therapy for patients with severe obesity is found to be bariatric surgery (BS). ${ }^{68}$ Patients with homozygous null mutations in LEPR are noted to maintain longterm weight loss following adjustable gastric banding. ${ }^{24}$ Despite the rare occurrences of complete loss of function mutations leading to obesity, 3 to $6 \%^{7-11}$ of patients with severe obesity carry a pathogenic mutation in the MC4R gene, making this the most common known genetic cause of severe obesity. ${ }^{69}$ Even though, it has been noted that patients with functional loss of both alleles of MC4R are unable to sustain long-term weight loss following $B S,{ }^{70}$ it is encouraging to note that weight loss trends in response to BS in patients with heterozygous MC4R mutations is similar to the response seen in general population with severe obesity. ${ }^{71}$ Similar results favoring BS in patients with $M C 4 R$ mutations have been supported in larger studies as well. ${ }^{72}$ Large multicenter studies are currently focused on studying the effect of MC4R mutations on long-term outcomes after BS.

BS has been reported as beneficial in adolescents with syndromic obesity. On following two patients for 6 and 17 months post one-anastomosis gastric bypass, both adolescents showed significant weight loss, improved lung function, weight-loss associated improvement in gait, and better quality of life postoperatively. ${ }^{73}$ Several case reports with such similar short-term follow-up periods have shown favorable outcomes of laparoscopic sleeve gastrectomy in adolescents with PWS. ${ }^{74}$ However, some studies have indicated that on an even longer term follow-up, for example,
10 years, BS did not produce sustainable long-term weight loss or comorbidity resolution in patients with PWS. ${ }^{75}$ It noted that the best mean percentage of total weight loss (\% TWL) was achieved at 2 years (24.7\%), but dropped to $23.3 \%$ at 3 years, $11.9 \%$ at 5 years, $4.1 \%$ at 8 years, and $0 \%$ at 10 years. ${ }^{75}$ Patients with other causes of syndromic obesity like BBS have shown good outcome with BS. ${ }^{76}$ A patient demonstrated BMI drop from 52.28 to $34.85 \mathrm{~kg} / \mathrm{m}^{2}$ when followed up for 3.5 years post laparoscopic Roux-en-Y gastric bypass as well as had significant improvement in his hypertension, hyperuricemia, and mobility. ${ }^{76}$ However, as currently literature is lacking in long-term outcome, it is recommended more studies focus on a longer follow-up period in patients with syndromic obesity treated with BS. This will help assess if the BS induced weight loss is durable and if the benefits on genetically determined comorbidities in these patients is long lasting.

\section{Conclusion}

Extreme obesity beginning before 5 years of age in the presence of hyperphagia and/or family history of obesity and a multisystem involvement warrants an evaluation for monogenic and syndromic causes of obesity. Early diagnosis of genetic obesity using various genetic testing including microarray, and whole genome sequencing is critical to identify the spectrum of mutations and develop therapeutic modalities including multidisciplinary care, targeted pharmacological approach using upcoming investigational drugs, or surgical options. Future progress for severe obesity might entail use of molecular pathological epidemiology to subclassify disease heterogeneity by linking etiologic factors and molecular biomarkers to enhance patient outcomes, especially in the era of precision medicine. ${ }^{77,78}$

Given the exponential weight gain and insatiable hyperphagia over subsequent follow-up visits, leading to severe obesity, next generation sequencing for rare genetic disorders of obesity was obtained in the patient's case highlighted here. Novel compound heterozygous mutations in the LEPR gene were identified. LEPR mutations are known to be associated with multiple endocrinopathies, so patient should be closely monitored for those in future. A multidisciplinary team approach was recommended. Dietary interventions such as consistent meal timing, environmental modifications such as monitored access to food, preplanned meals are some of the strategies advised to the caretakers until the child grows older and qualifies for targeted therapies such as an MC4R agonist. MC4R agonists have shown promise in reducing hyperphagia and decreasing weight.

Note

S.M. serves as a consultant to Rhythm Pharmaceuticals. R. S. has nothing to disclose. G.S. serves as a consultant to NovoNordisk and Rhythm Pharmaceuticals.

Funding

None. 


\section{Conflict of Interest}

None declared.

\section{References}

1 Ogden CL, Carroll MD, Lawman HG, et al. Trends in obesity prevalence among children and adolescents in the United States, 1988-1994 through 2013-2014. JAMA 2016;315(21):2292-2299

2 Thaker VV. Genetic and epigenetic causes of obesity. Adolesc Med State Art Rev 2017;28(02):379-405

3 Farooqi IS, O'Rahilly S. Mutations in ligands and receptors of the leptin-melanocortin pathway that lead to obesity. Nat Clin Pract Endocrinol Metab 2008;4(10):569-577

4 Huvenne H, Dubern B, Clément K, Poitou C. Rare genetic forms of obesity: clinical approach and current treatments in 2016. Obes Facts 2016;9(03):158-173

5 Farooqi S. Insights from the genetics of severe childhood obesity. Horm Res 2007;68(Suppl 5):5-7

6 Kleinendorst L, Abawi O, van der Kamp HJ, et al. Leptin receptor deficiency: a systematic literature review and prevalence estimation based on population genetics. Eur J Endocrinol 2020;182 (01):47-56

7 Vollbach H, Brandt S, Lahr G, et al. Prevalence and phenotypic characterization of MC4R variants in a large pediatric cohort. Int J Obes 2017;41(01):13-22

8 Hinney A, Volckmar AL, Knoll N. Melanocortin-4 receptor in energy homeostasis and obesity pathogenesis. Prog Mol Biol Transl Sci 2013;114:147-191

9 Farooqi IS, Keogh JM, Yeo GS, Lank EJ, Cheetham T, O'Rahilly S. Clinical spectrum of obesity and mutations in the melanocortin 4 receptor gene. N Engl J Med 2003;348(12):1085-1095

10 Hainerová IA, Lebl J. Treatment options for children with monogenic forms of obesity. World Rev Nutr Diet 2013;106:105-112

11 Kühnen P, Handke D, Waterland RA, et al. Interindividual variation in DNA methylation at a putative POMC metastable epiallele is associated with obesity. Cell Metab 2016;24(03):502-509

12 Foucan L, Larifla L, Durand E, et al. High prevalence of rare monogenic forms of obesity in obese guadeloupean afro-caribbean children. J Clin Endocrinol Metab 2018;103(02):539-545

13 Bohonowych J, Miller J, McCandless SE, Strong TV. The global Prader-Willi syndrome registry: development, launch, and early demographics. Genes (Basel) 2019;10(09):10

14 Dayton K, Miller J. Finding treatable genetic obesity: strategies for success. Curr Opin Pediatr 2018;30(04):526-531

15 Yu YH, Vasselli JR, Zhang Y, Mechanick JI, Korner J, Peterli R. Metabolic vs. hedonic obesity: a conceptual distinction and its clinical implications. Obes Rev 2015;16(03):234-247

16 Andermann ML, Lowell BB. Toward a wiring diagram understanding of appetite control. Neuron 2017;95(04):757-778

17 Roh E, Kim MS. Brain regulation of energy metabolism. Endocrinol Metab (Seoul) 2016;31(04):519-524

18 Srivastava G, Apovian CM. Current pharmacotherapy for obesity. Nat Rev Endocrinol 2018;14(01):12-24

19 Kuczmarski RJ, Ogden CL, Grummer-Strawn LM, et al. CDC growth charts: United States. Adv Data 2000;(314):1-27

20 Cuda SE, Censani M. Pediatric obesity algorithm: a practical approach to obesity diagnosis and management. Front Pediatr 2019;6:431

21 Krebs NF, Himes JH, Jacobson D, Nicklas TA, Guilday P, Styne D. Assessment of child and adolescent overweight and obesity. Pediatrics 2007;120(Suppl 4):S193-S228

22 Styne DM, Arslanian SA, Connor EL, et al. Pediatric obesityassessment, treatment, and prevention: an endocrine society clinical practice guideline. J Clin Endocrinol Metab 2017;102 (03):709-757

23 Gulati AK, Kaplan DW, Daniels SR. Clinical tracking of severely obese children: a new growth chart. Pediatrics 2012;130(06): $1136-1140$
24 Heymsfield SB, Avena NM, Baier L, et al. Hyperphagia: current concepts and future directions proceedings of the 2nd international conference on hyperphagia. Obesity (Silver Spring) 2014;22 (Suppl 1):S1-S17

25 Dykens EM, Maxwell MA, Pantino E, Kossler R, Roof E. Assessment of hyperphagia in Prader-Willi syndrome. Obesity (Silver Spring) 2007;15(07):1816-1826

26 Lowe MR, Butryn ML, Didie ER, et al. The Power of food scale. A new measure of the psychological influence of the food environment. Appetite 2009;53(01):114-118

27 Farooqi IS, Wangensteen T, Collins S, et al. Clinical and molecular genetic spectrum of congenital deficiency of the leptin receptor. $\mathrm{N}$ Engl J Med 2007;356(03):237-247

28 Miller JL. Approach to the child with Prader-Willi syndrome. J Clin Endocrinol Metab 2012;97(11):3837-3844

29 Alsaif M, Elliot SA, MacKenzie ML, Prado CM, Field CJ, Haqq AM. Energy metabolism profile in individuals with Prader-Willi syndrome and implications for clinical management: a systematic review. Adv Nutr 2017;8(06):905-915

30 Butler MG. Management of obesity in Prader-Willi syndrome. Nat Clin Pract Endocrinol Metab 2006;2(11):592-593

31 Deal CL, Tony M, Höybye C, Allen DB, Tauber M, Christiansen JS2011 Growth Hormone in Prader-Willi Syndrome Clinical Care Guidelines Workshop Participants. GrowthHormone Research Society workshop summary: consensus guidelines for recombinant human growth hormone therapy in Prader-Willi syndrome. J Clin Endocrinol Metab 2013;98(06): E1072-E1087

32 Carrel AL, Myers SE, Whitman BY, Eickhoff J, Allen DB. Long-term growth hormone therapy changes the natural history of body composition and motor function in children with prader-willi syndrome. J Clin Endocrinol Metab 2010;95(03):1131-1136

33 Koves IH, Roth C. Genetic and syndromic causes of obesity and its management. Indian J Pediatr 2018;85(06):478-485

34 Forsythe E, Beales PL. Bardet-Biedl syndrome. Eur J Hum Genet 2013;21(01):8-13

35 Mazaheri MM, Rae-Seebach RD, Preston HE, et al. The impact of Prader-Willi syndrome on the family's quality of life and caregiving, and the unaffected siblings' psychosocial adjustment. J Intellect Disabil Res 2013;57(09):861-873

36 Meienberg J, Bruggmann R, Oexle K, Matyas G. Clinical sequencing: is WGS the better WES? Hum Genet 2016;135(03):359-362

37 LaDuca H, Farwell KD, Vuong H, et al. Exome sequencing covers $>98 \%$ of mutations identified on targeted next generation sequencing panels. PLoS One 2017;12(02):e0170843

38 Bamshad MJ, Ng SB, Bigham AW, et al. Exome sequencing as a tool for Mendelian disease gene discovery. Nat Rev Genet 2011;12 (11):745-755

39 Das Bhowmik A, Gupta N, Dalal A, Kabra M. Whole exome sequencing identifies a homozygous nonsense variation in ALMS1 gene in a patient with syndromic obesity. Obes Res Clin Pract 2017;11(02):241-246

40 De Rosa MC, Chesi A, McCormack S, et al. Characterization of rare variants in MC4R in African American and Latino children with severe early-onset obesity. J Clin Endocrinol Metab 2019;104(07): 2961-2970

41 Ng SB, Turner EH, Robertson PD, et al. Targeted capture and massively parallel sequencing of 12 human exomes. Nature 2009;461(7261):272-276

42 Girirajan S, Brkanac Z, Coe BP, et al. Relative burden of large CNVs on a range of neurodevelopmental phenotypes. PLoS Genet 2011; 7(11):e1002334

43 Lappalainen T, Scott AJ, Brandt M, Hall IM. Genomic analysis in the age of human genome sequencing. Cell 2019;177(01):70-84

44 Federici G, Soddu S. Variants of uncertain significance in the era of high-throughput genome sequencing: a lesson from breast and ovary cancers. J Exp Clin Cancer Res 2020;39(01):46 
45 Dykens EM, Miller J, Angulo M, et al. Intranasal carbetocin reduces hyperphagia in individuals with Prader-Willi syndrome. JCI Insight 2018;3(12):3

46 Grolla E, Andrighetto G, Parmigiani P, et al. Specific treatment of Prader-Willi syndrome through cyclical rehabilitation programmes. Disabil Rehabil 2011;33(19-20):1837-1847

47 Paz-Filho G, Mastronardi CA, Licinio J. Leptin treatment: facts and expectations. Metabolism 2015;64(01):146-156

48 Wabitsch M, Funcke JB, Lennerz B, et al. Biologically inactive leptin and early-onset extreme obesity. N Engl J Med 2015;372 (01):48-54

49 Gonçalves JPL, Palmer D, Meldal M. MC4R agonists: structural overview on antiobesity therapeutics. Trends Pharmacol Sci 2018;39(04):402-423

50 Kühnen P, Clément K, Wiegand S, et al. Proopiomelanocortin deficiency treated with a melanocortin-4 receptor agonist. N Engl J Med 2016;375(03):240-246

51 Clément K, Biebermann H, Farooqi IS, et al. MC4R agonism promotes durable weight loss in patients with leptin receptor deficiency. Nat Med 2018;24(05):551-555

52 Clément K, van den Akker E, Argente J, et al; Setmelanotide POMC and LEPR Phase 3 Trial Investigators. Efficacy and safety of setmelanotide, an MC4R agonist, in individuals with severe obesity due to LEPR or POMC deficiency: single-arm, open-label, multicentre, phase 3 trials. Lancet Diabetes Endocrinol 2020;8 (12):960-970

53 Hainerová IA, Zamrazilová H, Sedláčková D, Hainer V. Hypogonadotropic hypogonadism in a homozygous MC4R mutation carrier and the effect of sibutramine treatment on body weight and obesity-related health risks. Obes Facts 2011;4(04):324-328

54 James WP, Caterson ID, Coutinho W, et al; SCOUT Investigators. Effect of sibutramine on cardiovascular outcomes in overweight and obese subjects. N Engl J Med 2010;363(10):905-917

$55 \mathrm{Lu} \mathrm{K}$, Chen Q, Li M, et al. Programmed cell death factor 4 (PDCD4), a novel therapy target for metabolic diseases besides cancer. Free Radic Biol Med 2020;159:150-163

56 Khera R, Murad MH, Chandar AK, et al. Association of pharmacological treatments for obesity with weight loss and adverse events: a systematic review and meta-analysis. JAMA 2016;315 (22):2424-2434

57 Senda M, Ogawa S, Nako K, Okamura M, Sakamoto T, Ito S. The glucagon-like peptide- 1 analog liraglutide suppresses ghrelin and controls diabetes in a patient with Prader-Willi syndrome. Endocr J 2012;59(10):889-894

58 Kim YM, Lee YJ, Kim SY, Cheon CK, Lim HH. Successful rapid weight reduction and the use of liraglutide for morbid obesity in adolescent Prader-Willi syndrome. Ann Pediatr Endocrinol Metab 2020;25(01):52-56

59 Sze L, Purtell L, Jenkins A, et al. Effects of a single dose of exenatide on appetite, gut hormones, and glucose homeostasis in adults with Prader-Willi syndrome. J Clin Endocrinol Metab 2011;96 (08):E1314-E1319

60 Salehi P, Hsu I, Azen CG, Mittelman SD, Geffner ME, Jeandron D. Effects of exenatide on weight and appetite in overweight adolescents and young adults with Prader-Willi syndrome. Pediatr Obes 2017;12(03):221-228

61 Lomenick JP, Buchowski MS, Shoemaker AH. A 52-week pilot study of the effects of exenatide on body weight in patients with hypothalamic obesity. Obesity (Silver Spring) 2016;24(06):1222-1225

62 Ando T, Haraguchi A, Matsunaga T, et al. Liraglutide as a potentially useful agent for regulating appetite in diabetic patients with hypothalamic hyperphagia and obesity. Intern Med 2014;53(16): 1791-1795
63 Zoicas F, Droste M, Mayr B, Buchfelder M, Schöfl C. GLP-1 analogues as a new treatment option for hypothalamic obesity in adults: report of nine cases. Eur J Endocrinol 2013;168(05): 699-706

64 Hamilton JK, Conwell LS, Syme C, Ahmet A, Jeffery A, Daneman D. Hypothalamic obesity following craniopharyngioma surgery: results of a pilot trial of combined diazoxide and metformin therapy. Int J Pediatr Endocrinol 2011;2011:417949

65 Brauner R, Serreau R, Souberbielle JC, et al. Diazoxide in children with obesity after hypothalamic-pituitary lesions: a randomized, placebo-controlled trial. J Clin Endocrinol Metab 2016;101(12): 4825-4833

66 Jafferany M, Patel A. Skin-picking disorder: a guide to diagnosis and management. CNS Drugs 2019;33(04):337-346

67 Zhao L. The gut microbiota and obesity: from correlation to causality. Nat Rev Microbiol 2013;11(09):639-647

68 Stefater MA, Wilson-Pérez HE, Chambers AP, Sandoval DA Seeley RJ. All bariatric surgeries are not created equal: insights from mechanistic comparisons. Endocr Rev 2012;33(04): 595-622

69 Paolini B, Maltese PE, Del Ciondolo I, et al. Prevalence of mutations in LEP, LEPR, and MC4R genes in individuals with severe obesity. Genet Mol Res 2016;15(03):15

70 Aslan IR, Ranadive SA, Ersoy BA, Rogers SJ, Lustig RH, Vaisse C. Bariatric surgery in a patient with complete MC4R deficiency. Int J Obes 2011;35(03):457-461

71 Hatoum IJ, Stylopoulos N, Vanhoose AM, et al. Melanocortin-4 receptor signaling is required for weight loss after gastric bypass surgery. J Clin Endocrinol Metab 2012;97(06):E1023-E1031

72 Valette M, Poitou C, Le Beyec J, Bouillot JL, Clement K, Czernichow S. Melanocortin- 4 receptor mutations and polymorphisms do not affect weight loss after bariatric surgery. PLoS One 2012;7(11): e48221

73 Tripodi M, Casertano A, Peluso M, et al. Prader-Willi syndrome: role of bariatric surgery in two adolescents with obesity. Obes Surg 2020;30(11):4602-4604

74 Martinelli V, Chiappedi M, Pellegrino E, et al. Laparoscopic sleeve gastrectomy in an adolescent with Prader-Willi syndrome: psychosocial implications. Nutrition 2019;61:67-69

75 Liu SY, Wong SK, Lam CC, Ng EK. Bariatric surgery for Prader-Willi syndrome was ineffective in producing sustainable weight loss: long term results for up to 10 years. Pediatr Obes 2020;15(01): e12575

76 Daskalakis M, Till H, Kiess W, Weiner RA. Roux-en-Y gastric bypass in an adolescent patient with Bardet-Biedl syndrome, a monogenic obesity disorder. Obes Surg 2010;20(01):121-125

77 Ogino S, Nishihara R, VanderWeele TJ, et al. Review article: the role of molecular pathological epidemiology in the study of neoplastic and non-neoplastic diseases in the era of precision medicine. Epidemiology 2016;27(04):602-611

78 Ogino S, Nowak JA, Hamada T, Milner DA Jr, Nishihara R. Insights into pathogenic interactions among environment, host, and tumor at the crossroads of molecular pathology and epidemiology. Annu Rev Pathol 2019;14:83-103

79 Eneli I, Xu J, Webster M, et al. Tracing the effect of the melanocortin-4 receptor pathway in obesity: study design and methodology of the TEMPO registry. Appl Clin Genet 2019;12:87-93

80 Hulbert AJ, Else PL. Basal metabolic rate: history, composition, regulation, and usefulness. Physiol Biochem Zool 2004;77(06): 869-876

81 Nelms M, Sucher KP, Lacey K, Roth SL. Nutrition Therapy and Pathophysiology. 2nd ed. Belmont, CA: Wadsworth, Cengage Learning; 2011 